\title{
Generation of R-Curve from 4ENF Specimens: An Experimental Study
}

\author{
V. Alfred Franklin' ${ }^{1}$ and T. Christopher ${ }^{2}$ \\ ${ }^{1}$ Faculty of Mechanical Engineering, Sardar Raja College of Engineering, Alangulam, \\ Tirunelveli 627808, India \\ ${ }^{2}$ Faculty of Mechanical Engineering, Government College of Engineering, Tirunelveli 627007, India \\ Correspondence should be addressed to V. Alfred Franklin; frank_vin@yahoo.com
}

Received 9 July 2014; Revised 21 October 2014; Accepted 23 October 2014; Published 11 November 2014

Academic Editor: Baozhong Sun

Copyright (C) 2014 V. Alfred Franklin and T. Christopher. This is an open access article distributed under the Creative Commons Attribution License, which permits unrestricted use, distribution, and reproduction in any medium, provided the original work is properly cited.

\begin{abstract}
The experimental determination of the resistance to delamination is very important in aerospace applications as composite materials have superior properties only in the fiber direction. To measure the interlaminar fracture toughness of composite materials, different kinds of specimens and experimental methods are available. This article examines the fracture energy of four-point end-notched flexure (4ENF) composite specimens made of carbon/epoxy and glass/epoxy. Experiments were conducted on these laminates and the mode II fracture energy, $G_{\text {IIC }}$, was evaluated using compliance method and was compared with beam theory solution. The crack growth resistance curve (R-curve) for these specimens was generated and the found glass/epoxy shows higher toughness values than carbon/epoxy composite. From this study, it was observed that R-curve effect in 4ENF specimens is quite mild, which means that the measured delamination toughness, $G_{\text {IIC }}$, is more accurate.
\end{abstract}

\section{Introduction}

Owing to their high stiffness and strength combined with low weight, polymer matrix composites have become more appropriate structural materials for aerospace applications. However, the usual laminated nature and the relatively low matrix strength make them particularly susceptible to delamination. The highly anisotropic nature of laminated composite structures causes a mismatch in mechanical properties between individual lamina within the laminate, which in turn can produce interlaminar crack initiation and propagation. For example, low velocity impact can generate relatively large delamination, which is highly detrimental to compressive load because of localized buckling phenomena [1]. Testing of thin skin stiffened panels designed for aircraft fuselage applications has shown that bond failure at the tip of the frame flange is a very important failure mode. Debonding also occurs when a thin-gage composite fuselage panel is allowed to buckle in service [2]. The growing use of composite materials in aircraft and spacecraft applications has motivated researchers to understand their fracture behaviour and damage mechanisms. Hence, fracture characterization of composites structures attains special relevancy.

Most of the composites currently in service contain only two-dimensional (in-plane) reinforcement and delamination remains an important failure mode in such composites. The development of standardised test methods to characterize the resistance to interlaminar crack propagation is necessary for two main reasons: (i) such tests offer the possibility to compare existing and new materials on the same basis and (ii) such tests offer reliable input data for new damage tolerance models. Unlike mode I DCB testing, mode II testing is not fully standardized by ASTM. There are standard test methods which are available for ENF [3], ELS [4], and calibrated endloaded split (C-ELS) test [5] specimens. In fact, the ENF test requires $a / L>0.7$ to obtain stable crack propagation [6], whereas in the ELS test $a / L>0.55$ is sufficient [7]. Stabilized ENF was not popular in round-robin trials [5]. Synthesizing the previous findings, it is shown that accurate and repeatable toughness values are obtained provided that the ratio of crack 
length to half-span length $(a / L)$ is 0.6 . Accuracy of data reduction considerations indicated a common range of $21 \leq$ $L / h \leq 29$ or, for $L=50 \mathrm{~mm}, 3.4 \mathrm{~mm} \leq 2 h \leq 4.7 \mathrm{~mm}$ for ENF specimens [8].

Martin and Davidson [9] proposed another version of mode II configuration, shown in Figure 1, called the 4ENF test, and this geometry encourages stable crack propagation so that an experimental compliance calibration can be applied for data reduction. Moreover just from the data of one test, mode II crack growth resistance curve can be generated. The advantages of $4 \mathrm{ENF}$ test are (i) simple coupon geometry, (ii) simple closed-form solution, (iii) propagation toughness which can be evaluated, and (iv) pure bending at the crack tip. The main drawback of 4ENF configuration is longitudinal sliding. During the year 1998, a draft mode II 4ENF test protocol [10] for an international round robin exercise was prepared [11], but it was not accepted as a standard test method because of frictional effects [12].

Fan et al. [13] introduced a new test method, named internal-notched flexure (INF) test, which was designed to measure the critical energy release rate of fiber reinforced composites under shear mode. The test applies three-point bending to a beam specimen that has an insert film embedded in the midthickness, thus named internal-notched flexure (INF) test, similar to central-notched flexure (CNF) test [14]. The main difference between the two tests is the placement of the specimen in the three-point bend device. Both tests use symmetrical three point loading, but the CNF test applies the load in the middle of the insert film with the span length longer than the insert film. The INF test, on the other hand, applies the load asymmetrically with respect to the insert film, with one end of the insert film being much closer to the loading pin than the other end. The delamination crack in the INF specimen is subject to concentrated forces only, without any moment, which is the same condition as that for $4 \mathrm{ENF}$ specimens of the same fiber lay-up. Therefore, the fracture mode introduced in the INF test should be the same as that in the 4ENF test, and the two tests should be subject to a pure shear mode of fracture. The stability during crack growth of different mode II fracture specimens is shown in Figure 2. Among these mode II specimens, 4ENF specimen shows better propagation stability.

The R-curve is the relationship between the fracture toughness and crack length. Applying 4ENF test, crack growth is stable under displacement control and the complete $\mathrm{R}$-curve can be determined from the data of just one test [15]. In many works the R-curve behavior, R-curve resistance, or J-resistance [16] was observed, which means that the fracture toughness increases with the crack size; this can be attributed to the fiber bridging and fiber pullout during the fracture $[17,18]$. These fibers increase the resistance to delamination.

In the present study, tests were conducted on carbon/epoxy and glass/epoxy laminates to estimate mode II fracture energy and the R-curves have been generated from the test data. However, the R-curve effect noticed was mild and that for carbon/epoxy specimen was almost insignificant.

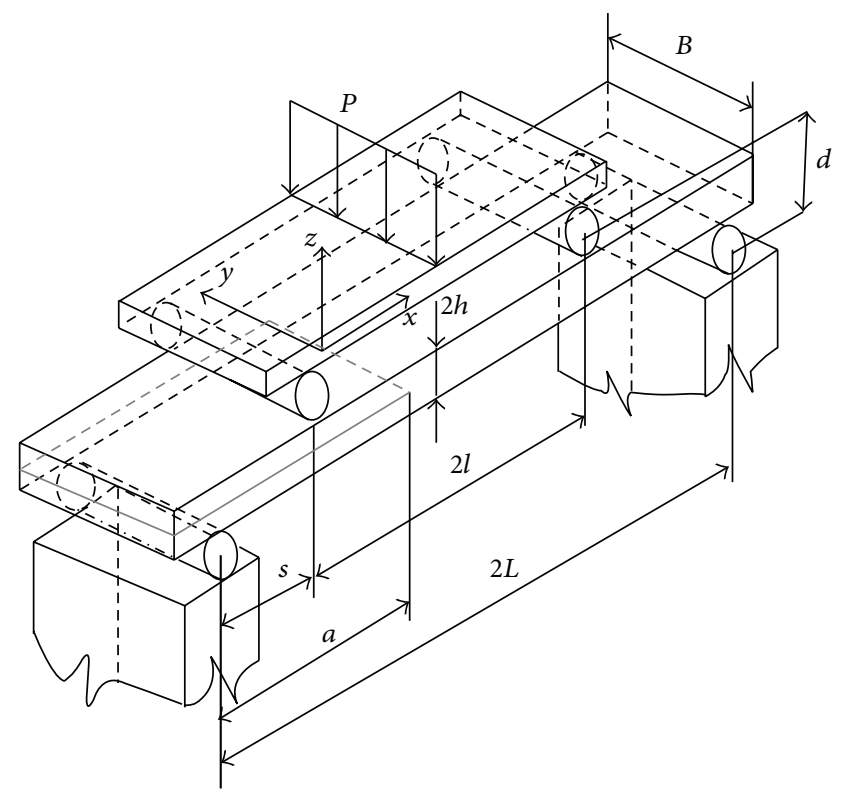

FIGURE 1: Four-point end-notched flexure (4ENF) specimen geometry.

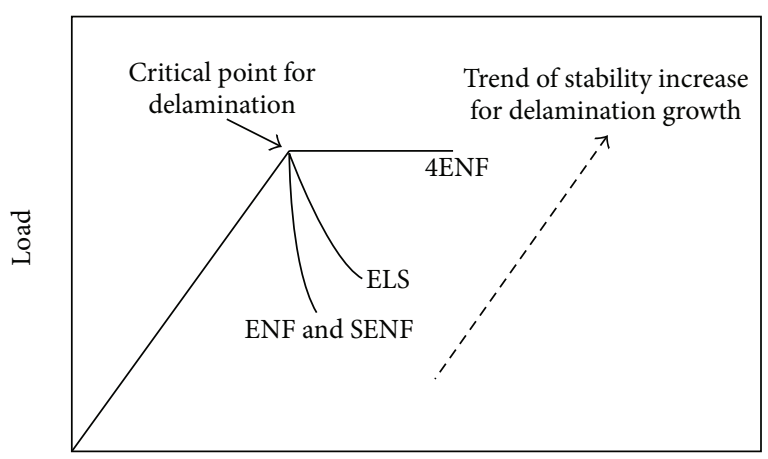

Displacement

FIgURE 2: Schematic showing the trend of crack growth stability under mode II [13].

\section{Factors Affecting Mode II Fracture Toughness}

2.1. Influence of Fiber Volume Fraction. Hunston et al. [19] studied the influence of fibre content on mode I delamination toughness and showed much higher $G_{I C}$ values for a composite which was resin rich than those for the same material with lower resin content. In the same way, experiments using the edge cracked torsion (ECT) specimen show a physically powerful influence of fibre content on mode III fracture toughness [20]. Davies et al. [21] examined mode II fracture toughness of glass/epoxy composites over a large range of fibre volume fraction using $4 \mathrm{ENF}$ test. The initiation and propagation fracture toughness versus fibre content are shown in Figures 3 and 4. From these figures, it is noted that the toughness decreases quite substantially with increasing fibre content. At high fiber contents, the 


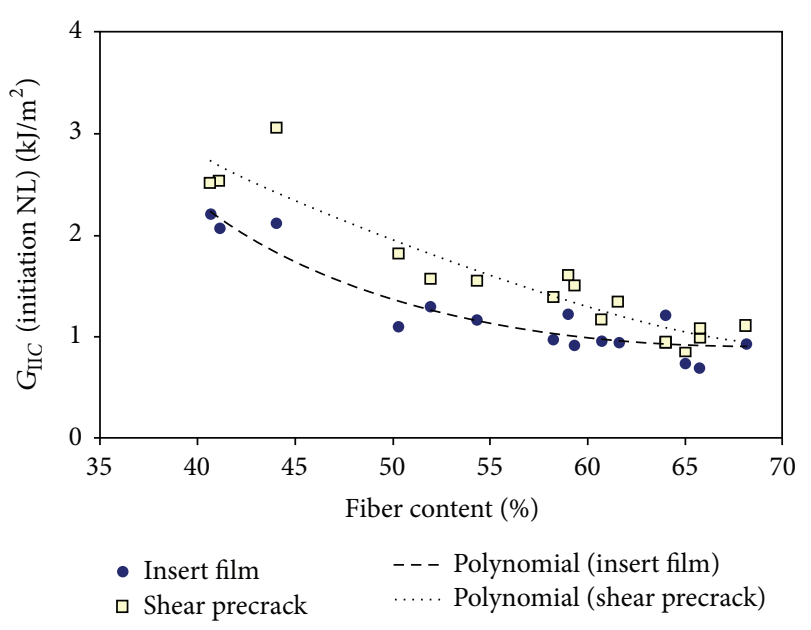

FIGURE 3: Influence of fiber volume fraction on initiation toughness [21].

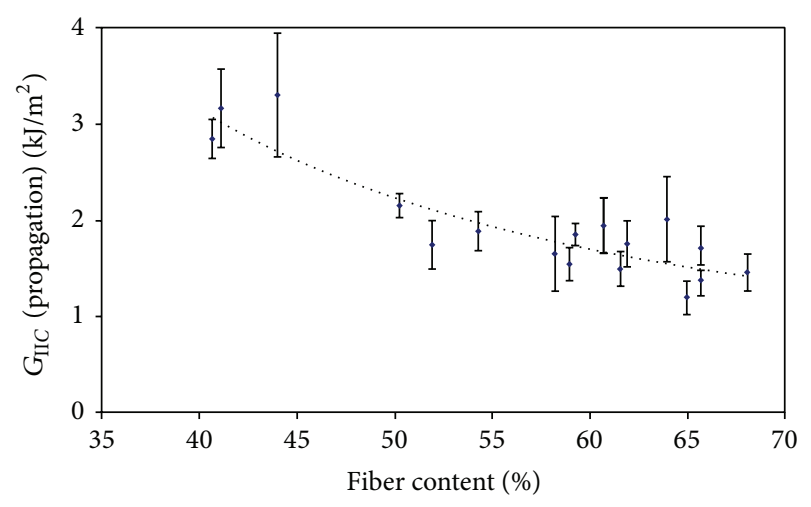

FIGURE 4: Influence of fiber volume fraction on propagation toughness [21].

delamination toughness assume a level of stability which is apparently dominated by fiber/matrix interfacial adhesion rather than matrix plasticity. Obviously, Table 1 summarises that there is a strong effect of fibre volume fraction on the initiation and propagation toughness. There are a lot of potential explanations for the large influence of fibre volume fraction on mode II interlaminar fracture toughness. But a more believable reason for the high toughness of the low fibre content specimens is plasticity effects at crack tip [19]. Shear fracture tests on adhesively bonded metal specimens were conducted by Chai [22] and a strong increase in mode II toughness was found as the adhesive layer thickness was increased. Similarly, a strong effect of resin film thickness on interlaminar fracture toughness of interleaved carbon fibre composites was shown by Carlsson [23].

2.2. Influence of Nose Distance. Kageyama et al. [12] studied the effect of nose distance $(d)$ on load-displacement characteristics with two fixtures A $(d=56 \mathrm{~mm})$ and B $(d=12 \mathrm{~mm})$. Figure 5 shows the load versus displacement curves obtained by using fixtures A and B. In both specimens, PTFE film was inserted between delamination surfaces. Stick-slip was

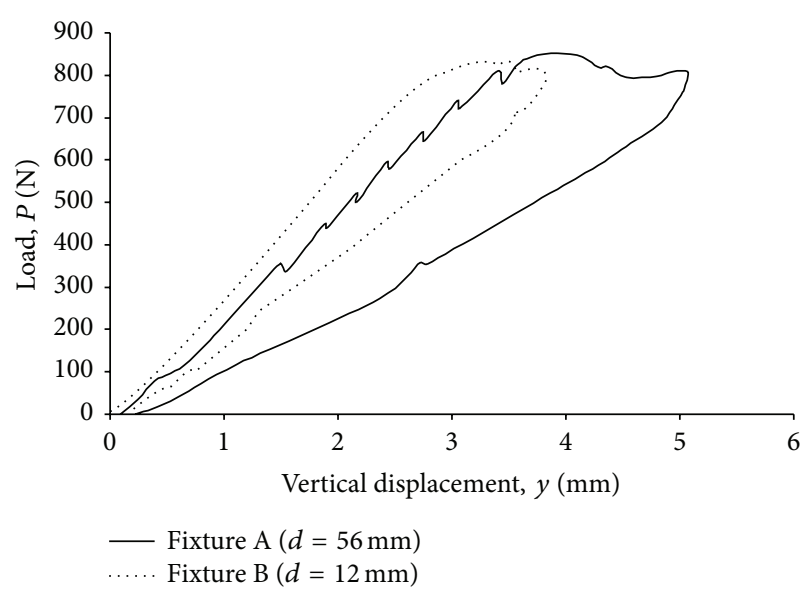

FIGURE 5: Influence of nose distance on load-displacement history [12].

observed when fixture A was used. While using fixture B, the effect of geometrical nonlinearity was minimized and linear relations were noticed at initial stage of loading and no stickslips occurred. Effect of geometrical nonlinearity was clearly observed when fixture A was used and that was not observed in fixture B. However, unsymmetrical loading can reduce the effect of geometrical nonlinearity, but data reduction method becomes very complicated. Hence, the nose distance should be as small as possible in order to avoid the effect of large deformation.

2.3. Influence of Inner Span Length. It was found [15] that when $l / L=0.4$, the propagation toughness is an average of $30 \%$ lower than the initiation toughness, and when $l / L=0.5$, the propagation toughness is $21 \%$ lower than the initiation toughness. This shows the influence of inner span length on fracture toughness.

Moreover, Table 2 summarizes mode II fracture toughness, $G_{\mathrm{IIC}}$, results for two inner span lengths, in which the averaged results of the $4 \mathrm{ENF}$ specimens with PTFE films at loading and supporting noses and between delamination surfaces are compared with those obtained by SENF test under crack shear displacement control [24, 25] according to JIS K7086 standards. From Table 2, it is noticed that if inner span length $(2 l)$ increases, $G_{\text {IIC }}$ also increases and vice versa.

2.4. Influence of Friction. In a finite element study, Schueker and Davidson [26] investigated that the differences in delamination toughness obtained by the ENF and 4ENF tests could be attributed to friction between the crack faces. Moreover the effect of friction increases with span ratio [27, 28]. Kageyama et al. [12] have shown that the experimental compliance does not agree well with the theoretical one. Assuming that the difference is due to friction between delamination surfaces, they estimated the coefficient of friction as 2.1 for an inner span of $50 \mathrm{~mm}$, and this value is much higher than the expected value. However, as elementary beam theory gives smaller value of theoretical compliance $\left(\lambda_{11}\right)$ than the exact elastic solution, the effect of friction might 
TABLE 1: Influence of fiber volume fraction on mode II toughness [21].

\begin{tabular}{lcc}
\hline Range of fiber volume fraction, $V_{f}$ & Initiation toughness $\left(\mathrm{kJ} / \mathrm{m}^{2}\right)$ & \multicolumn{2}{c}{ Propagation toughness $\left(\mathrm{kJ} / \mathrm{m}^{2}\right)$} \\
& Mean $(\mathrm{SD})$ & Mean $(\mathrm{SD})$ \\
\hline $40-45 \%$ & $2.13(0.07)$ & $3.04(0.45)$ \\
$>55 \%$ & $0.98(0.18)$ & $1.64(0.35)$ \\
\hline
\end{tabular}

TABLE 2: Influence of inner span on critical mode II interlaminar fracture toughness of carbon/epoxy 4ENF specimens.

\begin{tabular}{|c|c|c|c|c|}
\hline \multirow{2}{*}{ Method } & \multirow{2}{*}{ Inner span $2 l(\mathrm{~mm})$} & \multicolumn{3}{|c|}{$G_{\text {IIC }}\left(\mathrm{kJ} / \mathrm{m}^{2}\right)$} \\
\hline & & NL & $5 \%$ or $\max$ & Propagation \\
\hline \multirow{2}{*}{ 4ENF [39] } & 50 & 0.682 & 0.902 & 1.002 \\
\hline & 70 & 0.854 & 1.011 & 1.047 \\
\hline \multirow{2}{*}{$4 \mathrm{ENF}[12]$} & 50 & 0.525 & 0.692 & 0.767 \\
\hline & 70 & 0.563 & 0.666 & 0.690 \\
\hline SENF [24, 25] & & 1.041 & 1.261 & 1.225 \\
\hline
\end{tabular}

be larger than that estimated. The authors [12] presented a method to take into account the effect of friction of $4 \mathrm{ENF}$ specimen on delamination fracture toughness which is given by,

$$
G_{\mathrm{IIC}}=\frac{P_{c}^{2}}{2 B} \cdot \frac{\partial\left(2 C-\lambda_{11}\right)}{\partial a}=\frac{P_{c}^{2}\left(2 m_{1}-m_{o}\right)}{2 B} .
$$

Here

$$
\begin{gathered}
m_{1}=\frac{\partial C}{\partial a}=\frac{9 s^{2}}{8 E B h^{3}}\left(1-\frac{4 \mu h}{3 s}\right), \\
m_{o}=\frac{\partial \lambda_{11}}{\partial a}=\frac{9 s^{2}}{8 E B h^{3}} .
\end{gathered}
$$

Accuracy of (1) depends on the accuracy of theoretical value of compliance, $\lambda_{11}$. They concluded that the effect of friction has larger effect on $G_{\mathrm{IIC}}$ in $4 \mathrm{ENF}$ specimen. But Schuecker and Davidson [15] analyzed the effect of friction by using finite element analysis (VCCT), in view of the work reported by Kageyama et al. [12]. Table 3 presents the results obtained for friction coefficients $\mu=0.5$ and 1.0. The error caused by friction is obviously larger in $4 \mathrm{ENF}$ specimens, but it remains acceptably small. They argued that the introduction of friction combined with the damage model was the source of error in [12].

Cartié et al. [29] studied the influence of hydrostatic pressure on delamination fracture toughness of carbon/epoxy (IM7/977-2) composite pressure vessels and noted that the effect of pressure on mode I fracture toughness is insignificant. But they observed that mode II delamination resistance was increased by up to $25 \%$ for an increase in pressure from 4 to 900 bars. They observed that the crack initiation was unstable and higher $G_{\mathrm{IIC}}$ values were measured at initiation than during subsequent propagation. Table 4 shows the results obtained for both initiation and propagation and it is noted that there is a significant increase in initiation and propagation toughness values with increasing pressure. Figure 6 shows that, under mode I loading, there may be a small decrease in the fracture toughness and this drop cannot be considered to be significant. A significant influence
TABLE 3: Effect of friction on $G_{\text {IIC }}$ in 4ENF specimen in terms of percentage error [31].

\begin{tabular}{lccc}
\hline $\begin{array}{l}\text { Coefficient of } \\
\text { friction }\end{array}$ & \multicolumn{2}{c}{ Relative to nonfriction case } & Relative to \\
\hline 0.5 & VCCT & CBT & VCCT CBT \\
1.0 & -1.36 & 1.18 & 2.04 \\
\hline
\end{tabular}

of pressure on fracture toughness was noted under mode II loading. One possible reason for this is the influence of pressure on the friction between the two sliding surfaces. Friction forces will be directly proportional to the applied lateral pressure on the specimen faces so the work required to overcome these friction would be expected to increase the measured value of $G_{\mathrm{IIC}}$.

2.5. Influence of Measuring Techniques and Reduction Schemes. An experimental study to investigate the accuracy of the 4ENF test for the determination of mode II delamination toughness was conducted by Schuecker and Davidson [15] and it was observed that the 4ENF test gave higher values than the ENF test; the percentage difference increases with increasing the ratio of the inner span versus the outer one. They assumed that the error might be due to the inexact measuring techniques for determining load, deflection, and crack length. With different span ratio, $4 \mathrm{ENF}$ and ENF tests were conducted on unidirectional carbon/epoxy specimens and results were compared. The initiation and propagation tests were conducted and the fracture toughness was evaluated by compliance calibration method. The crack length was measured visually, using c-scan system and LVDT. The specimen deflection was determined from the testing machine's actuator displacement and from the average of two LVDT readings. ENF initiation tests were also performed in the same way. In the $4 \mathrm{ENF}$ test the compliance versus crack length curve was linear but in ENF test it was fit with a third-order polynomial. Initiation results show that the $4 \mathrm{ENF}$ test gives $2-12.7 \%$ higher values than that of the ENF test. By $4 \mathrm{ENF}$ propagation test, it was 
TABLE 4: Influence of hydrostatic pressure on mode I and mode II delamination toughness [29].

\begin{tabular}{|c|c|c|c|c|c|c|}
\hline \multirow[b]{2}{*}{ Pressure (bar) } & \multicolumn{3}{|c|}{ Initiation ( $5 \% \max )$} & \multicolumn{3}{|c|}{ Propagation $(a=55 \mathrm{~mm})$} \\
\hline & 4 & 300 & 900 & 4 & 300 & 900 \\
\hline Average mode I delamination toughness, $G_{I C}\left(J / \mathrm{m}^{2}\right)$ & 406 & 397 & 363 & 766 & 719 & 682 \\
\hline Average mode II delamination toughness, $G_{\text {IIC }}\left(\mathrm{J} / \mathrm{m}^{2}\right)$ & 1548 & 1842 & 1812 & 944 & 1165 & 1285 \\
\hline
\end{tabular}

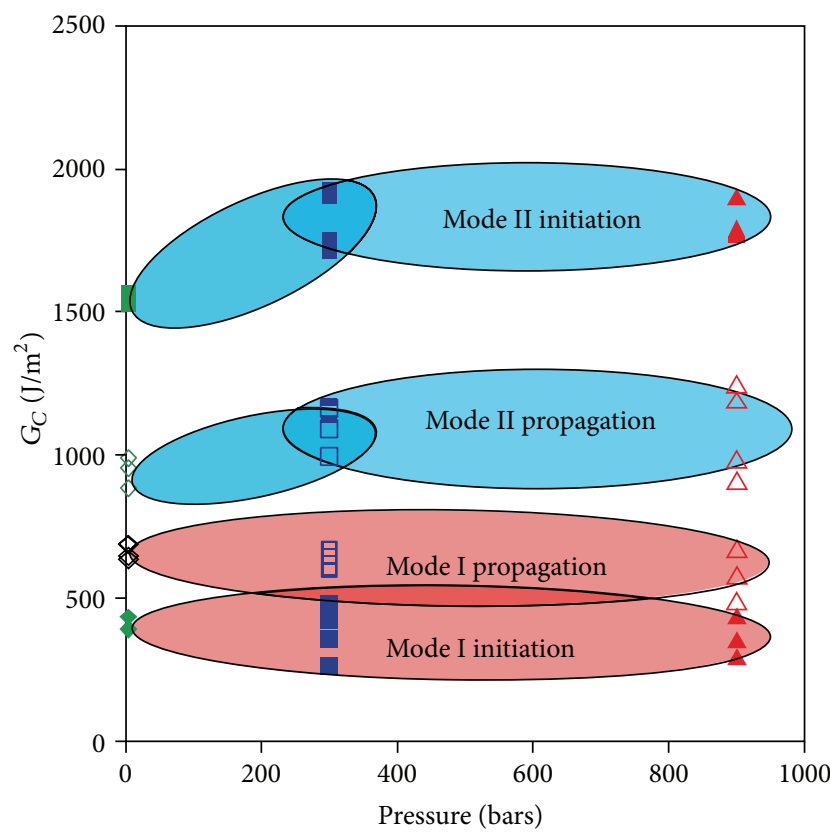

FIGURE 6: Influence of applied hydrostatic pressure on mode I and mode II fracture energy: a summary [29].

observed that the propagation toughness is $20-30 \%$ higher than the initiation one. They concluded that if compliance and crack length are measured accurately then both 4ENF and ENF tests will produce the same toughness values.

In the same way, Fan et al. [13] conducted INF and ENF tests on glass/polyester material to estimate mode II fracture energy. The average value at the onset of delamination was found as $G_{\text {IIC }}^{\mathrm{ENF}}=1584 \pm 85 \mathrm{~J} / \mathrm{m}^{2}$ and $G_{\mathrm{IIC}}^{\mathrm{INF}}=1532 \pm 81 \mathrm{~J} / \mathrm{m}^{2}$, respectively. This also shows that the initiation toughness values are closer if the parameters are measured accurately.

2.6. Influence of Fracture Criteria. Even though there is a progress in interlaminar fracture testing, uncertainty remains on determination of the onset of delamination growth from the starter crack, commonly designated as "crack initiation." This is a predominantly significant issue, because initiation fracture toughness is believed to be the most relevant for design purposes. In fact, due to the nesting inherent to unidirectional specimens, fibers above and below the midplane tend to bridge the delamination as it grows from the insert, giving rise to an R-curve effect. However, fiber bridging is considered an artefact of the DCB specimen that does not occur in structural composites [30]. Ideally, crack initiation could be defined by observation at one of the

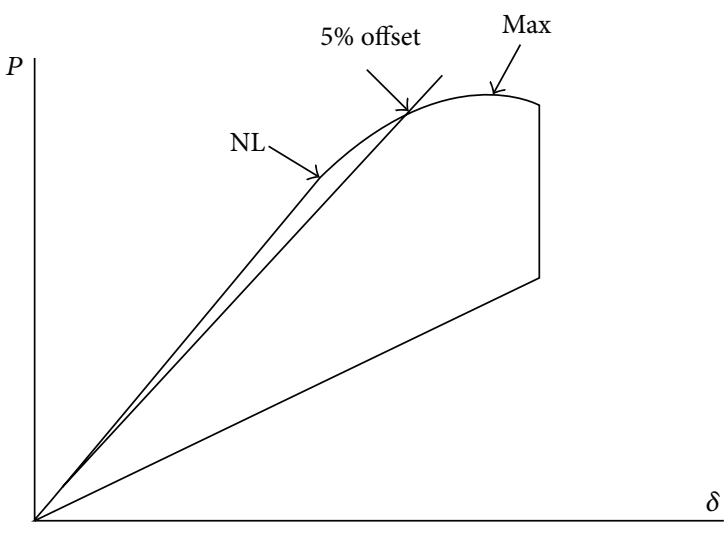

FIGURE 7: Schematic representing different initiation criteria [31].

specimen edges and this definitely introduces some degree of operator dependency. According to the nonlinearity (NL) criterion, initiation is taken at the point where the $P-\delta$ curve deviates from linearity. The NL criterion yields the most conservative toughness values. On the other hand, the 5\% offset or maximum load (5\%-max) criterion defines initiation at the lowest displacement point among the $5 \%$ offset and the maximum load. The previous one is obtained by intersecting the load-displacement curve with a line corresponding to compliance 5\% higher than the initial one (Figure 7). The maximum load criterion is unambiguous and seems to lead to lower scatter [30]. However, it yields higher toughness values than the NL criterion and the $5 \% \mathrm{C}$, which is also used in fracture testing of metals. The finite element model [31] predicted early deviations from linearity as a result of large process zones in ENF and ELS specimens. On the other hand, very accurate results were obtained with the $4 \mathrm{ENF}$ specimens, in spite of the relatively small starter crack. This is due to the crack length independent critical load. As described in [32], there is no clear physical meaning of the nonlinear load point in the ENF test. Thus, critical load will be taken as the maximum load point [8] since it coincides with actual initiation. Moreover from an international collaborative test program [11], it is noticed that ENF, ELS, and 4ENF tests gave similar fracture toughness results from the insert when maximum load criteria were used.

\section{Experimental Work}

3.1. Materials and Specimen Preparation. The materials used in the present study were unidirectional glass/epoxy and carbon/epoxy composites. The glass fibres of $300 \mathrm{gsm}$ were impregnated by hand lay-up with an epoxy resin (LY 556), 
with hardener HY951 in the ratio of approximately $10: 1$ to control the curing action and the degree of hardness of the cured film. The initial crack was made by introducing a thin Teflon film of thickness $13 \mu \mathrm{m}$ during stacking procedure. The laminate was prepared by hand lay-up and was postcured to stabilize the matrix property. Another material used in the present study was carbon/epoxy prepreg with a fiber volume fraction of $60 \%$. As before, the starter crack was obtained by placing the PTFE film at the mid-plane during stacking procedure and the laminate was cured at $180^{\circ} \mathrm{C}$ under a pressure of about 6 bars.

\subsection{Experimental Procedures. The specimens were tested} under a displacement rate of $1 \mathrm{~mm} / \mathrm{min}$, on a test frame with 3-ton capacity load cell. Typewriter correction fluid was applied on the thickness side of specimens and markings were made at a regular interval of $1 \mathrm{~mm}$. The machine crosshead displacement transducer was used to record upper loading point displacements, while crack length measurements were made visually with the help of travelling microscope. Zile and Tamuzs [33] experimentally found that the compliance data and their derivatives obtained from the continuous loading tests were very similar to load-unload-reload test. This means that both the loading techniques can be used to obtain critical energy release rate. Hence, the continuous loading test was adopted in the present study.

\section{Experimental Data Reduction}

Linear elastic fracture mechanics (LEFM) became a common practice to characterize the resistance to delamination. There are competing terminologies in literatures, such as fracture toughness, average fracture energy, J-integral, work of fracture, and critical strain energy release rate. In the present study, the critical strain energy release rate is used to characterize the R-curve.

4.1. Compliance Calibration. The compliance calibration method is superior to the compliance fitting method in case of non-self-similar crack advance [34]. It was shown [35] that, under displacement control, $\partial C / \partial a<0$ and this means that the crack (delamination) growth is stable. According to beam theory and finite element results $[26,35]$, a linear relationship between the compliance and crack length was observed. One of the most accurate data reduction methods to determine delamination toughness from $4 \mathrm{ENF}$ test data is compliance calibration technique (as compared to beam theory and finite element analysis if the crack length is measured accurately). Because of that, it was shown that beam theory and finite element based data reduction techniques can produce errors in toughness values $[27,28]$ due to the fact that it is difficult to accurately determine the bending stiffness of each test specimen. But compliance calibration data reduction is a direct method that assumes linear elastic behaviour and self-similar crack advance. Hence, any errors due to uncertainties in the geometric and/or material properties of each test specimen can be avoided. Mode II interlaminar fracture toughness was reduced from 4ENF test data using an experimental compliance calibration method with the compliance expression [10] as

$$
C=C_{o}+m a,
$$

and the fracture toughness is evaluated by

$$
G_{\text {IIC }}=\frac{P_{c}^{2}}{2 B} \cdot \frac{\partial C}{\partial a}=\frac{P_{c}^{2}}{2 B} \cdot m .
$$

4.2. Beam Analysis. Using beam theory, Zile and Tamuzs [33] derived an expression for mode II fracture toughness which is given by

$$
G_{\mathrm{IIC}}=\frac{3 P_{c}^{2} L^{2}}{32 B E_{11} I} .
$$

By unit load theorem, an expression for mode II fracture toughness is given by [31]

$$
G_{\mathrm{IIC}}=\frac{3 P_{c}^{2} s^{2}}{64 B E_{11} I} .
$$

\section{Results and Discussions}

In Section 2 of this paper, various factors affecting mode II fracture toughness (namely, fiber volume fraction, loading nose distance, inner span length, coefficient of friction, measuring techniques, and initiation criteria on the fracture) of $4 \mathrm{ENF}$ specimens were revived. This will give an overview about 4ENF specimen and testing to the beginners. In the second part of the paper (Section 3), fracture tests were carried out on 4ENF specimens made of carbon/epoxy and glass/epoxy and the load-displacement plot was shown in Figure 8 . These plots indicate essentially linear behaviour up to crack initiation. Figure 9 shows the compliance fitting plot established from fracture tests. The relation between compliance and crack length is observed as linear and the slope of these trend lines gives the value of $(\partial C / \partial a)$. Using these slope values, the $G_{\text {IIC }}$ was evaluated and tabulated in Table 6. The propagation values are found little below the initiation values and the minimum initiation values are measured directly from the insert film during propagation. Thus, there was always some unstable growth during the initial crack increment. Afterwards, crack growth was always stable and the load at which the crack advanced remained nearly constant. A complete R-curve has been generated from this test data; however, as the critical load was almost equal during propagation, there would be little variation in energy release rate with crack length. Considering (4), the fracture toughness is directly proportional to the slope of the compliance versus crack length curve. Therefore, the error between the different ways of determining $G_{\text {IIC }}$ depends on $\partial C / \partial a$ only.

The present test produces very stable crack growth. Figure 10 shows mode II interlaminar toughness versus crack length curves (resistance curves) at fibre volume fractions of about $60 \%$. For each composite specimen, the toughness increases to some extent during crack propagation. Also, it 
TABLE 5: Experimental delamination fracture energy from literatures.

\begin{tabular}{|c|c|c|c|c|c|c|c|c|}
\hline \multirow{2}{*}{ Material } & \multicolumn{4}{|c|}{ Initiation $\left(\mathrm{J} / \mathrm{m}^{2}\right)$} & \multicolumn{4}{|c|}{ Propagation $\left(\mathrm{J} / \mathrm{m}^{2}\right)$} \\
\hline & ENF & ELS & ONF & $4 \mathrm{ENF}$ & ENF & ELS & ONF & $4 \mathrm{ENF}$ \\
\hline Carbon/epoxy [33] & - & - & - & 610 & - & - & - & 1160 \\
\hline $\begin{array}{l}\text { Carbon/epoxy [40] } \\
\text { IM7/8552 }\end{array}$ & - & - & - & 1334 & - & - & - & - \\
\hline $\begin{array}{l}\text { Glass/epoxy [40] } \\
\text { S2/8552 }\end{array}$ & - & - & - & 1759 & - & - & - & - \\
\hline Glass/epoxy [41] & 2115 & - & - & - & - & - & - & - \\
\hline Glass/polyester [42] & - & 713 & 730 & - & - & - & 2787 & - \\
\hline Glass/polyester [43] & 496 & - & - & - & - & - & - & - \\
\hline Carbon/PEEK [44] & - & 1730 & - & - & - & 2890 & - & - \\
\hline Carbon/PES [45] & - & 1250 & - & - & - & 1850 & - & - \\
\hline C/HG9106 [46] & 335 & 565 & - & - & - & 800 & - & - \\
\hline Graphite/epoxy [47] & 875 & - & - & - & - & - & - & - \\
\hline T300/976 [48] & 450 & - & - & - & - & - & - & - \\
\hline IM7/977-2 [48] & 994 & - & - & - & - & - & - & - \\
\hline IM7/977-2 [49] & 910 & - & - & - & - & - & - & - \\
\hline Glass/polyprop. [18] & 3800 & - & - & - & - & - & - & - \\
\hline CYCOM 982 [50] & 1850 & - & - & - & - & - & - & - \\
\hline APC-2 [50] & 2730 & - & - & - & - & - & - & - \\
\hline
\end{tabular}

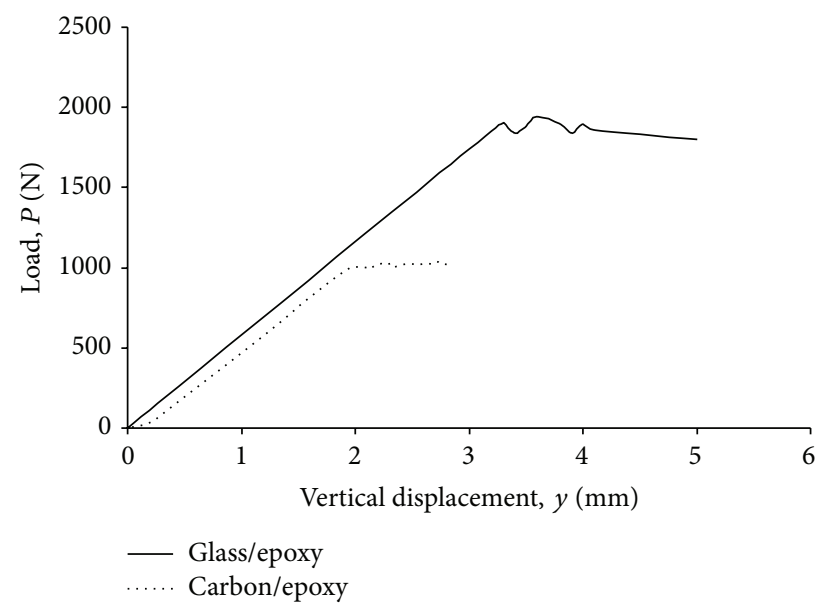

FIGURE 8: Load-displacement plot for carbon/epoxy and glass/epoxy specimens.

is noticed that glass/epoxy specimen shows a higher resistance to delamination than carbon/epoxy. For glass/epoxy specimens, the R-curves show a mild upward trend with the delamination growth, whereas for carbon/epoxy it is almost flat. However, no extensive fiber bridging was noticed as mentioned in $[21,33]$.

The influence of specimen configuration and material on $G_{\text {IIC }}$ is presented in Table 5 from previous literature. From Tables 1,5 , and 6 , it is noticed that the toughness values obtained in the present study are comparable with published test data. From Table 6, it is observed that beam theory estimates a higher initiation and propagation toughness as

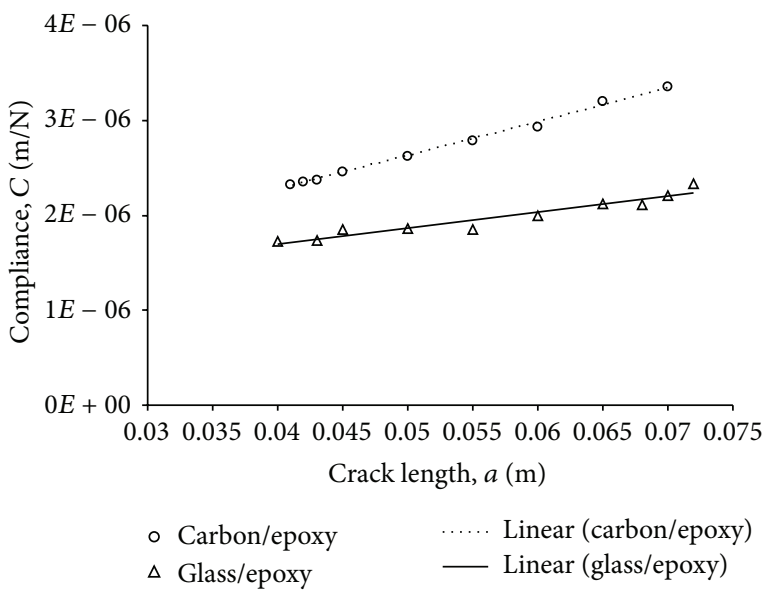

FIGURE 9: Linear curve fitting of compliance by compliance fitting method.

compared to compliance calibration method. This difference may be due to the measurement inaccuracy in flexural rigidity or in crack length. However, a good agreement was noticed between these two methods. Captivatingly, CBT (see (6)) gave reasonably accurate results for the 4ENF specimen, in spite of the relatively small starter crack. But higher $\%$ of error in delamination toughness was noticed with (5). In fact, (6) predicts that the critical load does not depend on the crack length and thus remains constant throughout propagation. From this study, it is concluded that the R-curve effect noticed in $4 \mathrm{ENF}$ specimens was very mild as compared to mode I fracture test [36-38]. 
TABLE 6: Mode II delamination toughness from present experiments.

\begin{tabular}{|c|c|c|c|c|c|c|}
\hline \multirow{2}{*}{ Material } & \multirow{2}{*}{$E_{11}(\mathrm{GPa})$} & \multirow{2}{*}{$2 h(\mathrm{~mm})$} & \multicolumn{2}{|c|}{ Initiation toughness $\left(\mathrm{J} / \mathrm{m}^{2}\right)$} & \multicolumn{2}{|c|}{ Propagation toughness $\left(\mathrm{J} / \mathrm{m}^{2}\right)$} \\
\hline & & & $\mathrm{CC}(4)$ & CBT (6) & $\mathrm{CC}(4)$ & CBT (6) \\
\hline Carbon/epoxy & 131 & 3.24 & 952 & 1105 & 910 & 1038 \\
\hline Glass/epoxy & 38 & 5.96 & 1905 & 2109 & 1807 & 2022 \\
\hline
\end{tabular}

Width, $B=20 \mathrm{~mm} ; 2 L=100 \mathrm{~mm} ; s=20 \mathrm{~mm} ; V_{f}=60 \%$.

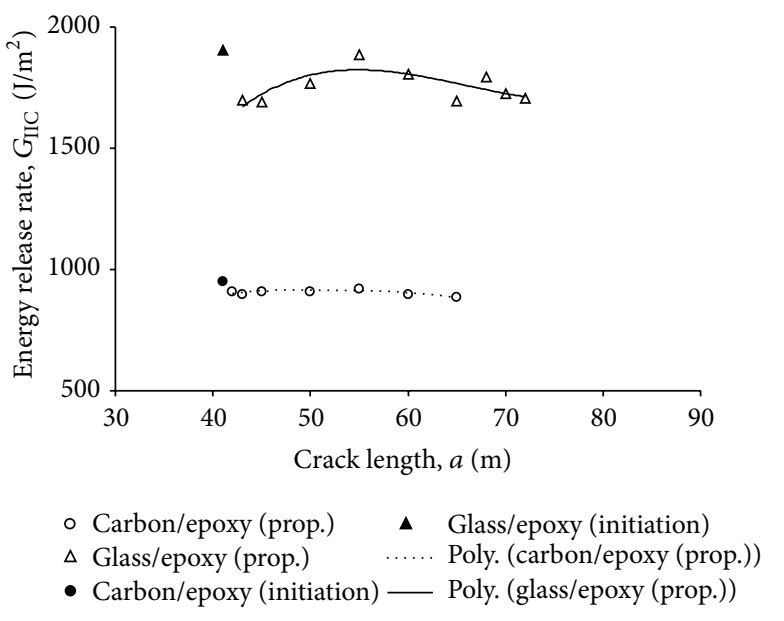

FIGURE 10: Crack growth resistance curve (R-curve) of 4ENF specimens.

\section{Concluding Remarks}

An experimental study was carried out on 4 ENF specimens made of glass/epoxy and carbon/epoxy. From experiments, it is noticed that the $4 \mathrm{ENF}$ specimen is well suited for measuring mode II delamination toughness and provides full resistance curves. From Table 6 and Figure 10, it is observed that the 4ENF specimen made of glass/epoxy shows higher resistance to delamination than carbon/epoxy composite. Moreover the experimental resistance curves showed that there was no significant toughening and hence no considerable fibre bridging was observed. Thus the R-curve effect was quite mild, providing accurate value of $G_{\text {IIC }}$. Since the variation in load (after initiation) with crack length was almost constant, all initiation criteria, namely, NL, 5\% C, and maximum load, estimate almost equal $G_{\text {IIC }}$ values.

\section{Nomenclature}

ll4ENF: Four-point bend end-notched flexure

a: Crack length

$B: \quad$ Specimen width

$C$ : $\quad$ Compliance of the specimen

$d$ : $\quad$ Nose distance

$E$ : Longitudinal tensile modulus

$G_{\text {II }}$ : Mode II strain energy release rate

$G_{13}$ : Shear modulus

$G_{I C}$ : Mode I fracture toughness or critical strain energy release rate

$G_{\text {IIC }}$ Mode II fracture/delamination toughness 2h: Specimen thickness

I: $\quad$ Area moment of inertia

2L: Outer span

2l: Inner span

$m$ : Slope of C-a plot

$P_{c}:$ Critical load

$s$ : Distance from one of the specimen supports to the nearest loading point

$V_{f}$ : Fiber volume fraction

$y: \quad$ Displacement at mid span

$\lambda_{11}$ : Theoretical compliance of $4 \mathrm{ENF}$ specimen without friction

$\mu$ : Coefficient of friction.

\section{Conflict of Interests}

The authors declare that there is no conflict of interests regarding the publication of this paper.

\section{References}

[1] A. B. de Morais, C. C. Rebelo, P. M. S. T. de Castro, A. T. Marques, and P. Davies, "Interlaminar fracture studies in Portugal: past, present and future," Fatigue \& Fracture of Engineering Materials \& Structures, vol. 27, no. 9, pp. 767-773, 2004.

[2] T. K. O’Brien, "Fracture mechanics of composite delamination," in ASM Handbook, Composites, vol. 21, pp. 241-245, ASM International, 2001.

[3] "Testing methods for interlaminar fracture toughness of carbon fiber reinforced plastics," Japanese Industrial Standard Group, JIS K-7086-1993,1993.

[4] B. R. K. Blackman, A. J. Brunner, and J. G. Williams, "Mode II fracture testing of composites: a new look at an old problem," Engineering Fracture Mechanics, vol. 73, no. 16, pp. 2443-2455, 2006.

[5] ISO, "Fibre-reinforced plastic composites-determination of the mode II fracture resistance for unidirectionally reinforced materials using the calibrated end-loaded split (C-ELS) test and an effective crack length approach," ISO 15114:2014, 2014.

[6] L. A. Carlsson, J. W. Gillespie Jr., and R. B. Pipes, "On the analysis and design of the end notched flexure (ENF) specimen for mode II testing," Journal of Composite Materials, vol. 20, no. 6, pp. 594-604, 1986.

[7] H. Wang and T. Vu-Khanh, "Use of end-loaded-split (ELS) test to study stable fracture behaviour of composites under mode II loading," Composite Structures, vol. 36, no. 1-2, pp. 71-79, 1996.

[8] B. D. Davidson and S. S. Teller, "Recommendations for an ASTM standardized test for determining $G_{I I c}$ of unidirectional laminated polymeric matrix composites," Journal of ASTM International, vol. 7, no. 2, Article ID JAI102619, 2010. 
[9] R. H. Martin and B. Davidson, "Mode II fracture toughness evaluation using a four point bend end notched flexure test," in Proceedings of the 4th International Deformation and Fracture of Composites Conference, pp. 243-252, London, UK, 1997.

[10] R. H. Martin, "Protocol for the determination of the mode II delamination resistance of unidirectional fiber reinforced polymer matrix composites using the four point bend end notched flexure (4ENF) specimen," MERL, reference 8-1-98. Protocol used for VAMAS Round robin tests, 1998.

[11] P. Davies, G. D. Sims, B. R. K. Blackman et al., "Comparison of test configurations for determination of mode II interlaminar fracture toughness results from international collaborative test programme," Plastics, Rubber and Composites, vol. 28, no. 9, pp. 432-437, 1999.

[12] K. Kageyama, I. Kimpara, T. Suzuki, H. Ohsawa, M. Kanai, and H. Tsuno, "Effects of test conditions on mode II interlaminar fracture toughness of four-point ENF specimens," in Proceedings of the 12th International Conference on Composite Materials, pp. 362-369, Paris, France, 1999.

[13] C. Fan, P. Y. B. Jar, and J. J. R. Cheng, "Internal-notched flexure test for measurement of mode II delamination resistance of fibre-reinforced polymers," Journal of Composites, vol. 2013, Article ID 695862, 7 pages, 2013.

[14] H. Maikuma, J. W. Gillespie, and J. M. Whitney, "Analysis and experimental characterization of the center notch flexural test specimen for mode II interlaminar fracture," Journal of Composite Materials, vol. 23, no. 8, pp. 756-786, 1989.

[15] C. Schuecker and B. D. Davidson, "Evaluation of the accuracy of the four-point bend end-notched flexure test for mode II delamination toughness determination," Composites Science and Technology, vol. 60, no. 11, pp. 2137-2146, 2000.

[16] K. Tohgo, D. Fukuhara, and A. Hadano, "The influence of debonding damage on fracture toughess and crack-tip field in glass-particle-reinforced Nylon 66 composites," Composites Science and Technology, vol. 61, no. 8, pp. 1005-1016, 2001.

[17] C.-A. Wang, Y. Huang, and Z. Xie, "Improved Resistance to damage of silicon carbide-whisker-reinforced silicon nitridematrix composites by whisker-oriented alignment," Journal of the American Ceramic Society, vol. 84, no. 1, pp. 161-164, 2001.

[18] G. Reyes V. and W. J. Cantwell, "The mechanical properties of fibre-metal laminates based on glass fibre reinforced polypropylene," Composites Science and Technology, vol. 60, no. 7, pp. 10851094, 2000.

[19] D. L. Hunston, R. J. Moulton, J. J. Johnston, and W. D. Bascom, "Matrix resin effects in composite delamination: mode I fracture aspects," in ASTM STP 937, N. J. Johnston, Ed., pp. 7494, American Society for Testing and Materials, Philadelphia, Pa, USA, 1987.

[20] X. Li, L. A. Carlsson, and P. Davies, "Influence of fiber volume fraction on mode III interlaminar fracture toughness of glass/epoxy composites," Composites Science and Technology, vol. 64, no. 9, pp. 1279-1286, 2004.

[21] P. Davies, P. Casari, and L. A. Carlsson, "Influence of fibre volume fraction on mode II interlaminar fracture toughness of glass/epoxy using the 4ENF specimen," Composites Science and Technology, vol. 65, no. 2, pp. 295-300, 2005.

[22] H. Chai, "Shear fracture," International Journal of Fracture, vol. 37, no. 2, pp. 137-159, 1988.

[23] L. A. Carlsson, "Fracture of laminated composites with interleaves," in Fracture of Composites, E. A. Armanios, Ed., vol. 120-121 of Key Engineering Material, pp. 489-520, Trans Tech Publications, 1996.
[24] K. Kageyama, M. Kikuchi, and N. Yanagisawa, "Stabilized end notched flexure test. Characterization of Mode II interlaminar crack growth," in Proceedings of the 3rd Symposium on Composite Materials: Fatigue and Fracture, T. K. O'Brien, Ed., ASTM STP 1110, pp. 210-225, American Society for Testing and Materials, Philadelphia, Pa, USA, November 1989.

[25] K. Kageyama, I. Kimpara, I. Ohsawa, M. Hojo, and S. Kabashima, "Mode I and mode II delamination growth of interlayer toughened carbon/epoxy (T800H/3900-2) composite system," in Composite Materials: Fatigue and Fracture-Fifth Volume, R. H. Martin, Ed., vol. 5 of ASTM STP 1230, pp. 19-37, American Society for Testing and Materials, 1995.

[26] C. Schueker and B. D. Davidson, "Effect of friction on the perceived mode II delamination toughness from three- and fourpoint bend end notched flexure tests," in Composite Structures: Theory and Practice, P. E. Grant and C. Q. Rousseau, Eds., vol. 1383, pp. 334-344, ASTM STP, American Society of Testing of Materials, 2000.

[27] T. K. O’Brien, G. B. Murri, and S. A. Salpekar, "Interlaminar shear fracture toughness and fatigue thresholds for composite materials," in Composite Materials: Fatigue and Fracture, P. A. Lagace, Ed., vol. 2 of ASTM STP 1012, pp. 222-250, American Society of Testing of Materials, 1989.

[28] B. D. Davidson, C. S. Altonen, and J. J. Polaha, "Effect of stacking sequence on delamination toughness and delamination growth behavior in composite end-notched flexure specimens," in Composite Materials: Testing and Design (12th Volume), ASTM STP 1274, R. B. Deo and C. R. Staff, Eds., pp. 393-413, American Society of Testing of Materials, Philadelphia, Pa, USA, 1996.

[29] D. Cartié, P. Davies, M. Peleau, and I. K. Partridge, "The influence of hydrostatic pressure on the interlaminar fracture toughness of carbon/epoxy composites," Composites B: Engineering, vol. 37, no. 4-5, pp. 292-300, 2006.

[30] P. Davies, B. R. K. Blackman, and A. J. Brunner, "Standard test methods for delamination resistance of composite materials: current status," Applied Composite Materials, vol. 5, no. 6, pp. 345-364, 1998.

[31] A. B. de Morais and M. F. S. F. de Moura, "Evaluation of initiation criteria used in interlaminar fracture tests," Engineering Fracture Mechanics, vol. 73, no. 16, pp. 2264-2276, 2006.

[32] B. D. Davidson, “Towards an ASTM standardized test for determining GIIc of unidirectional laminated polymeric matrix composites," in Proceedings of the 21st Annual American Society for Composites Technical Conference, P. K. Mallick, Ed., DEStech Publications, September 2006.

[33] E. Zile and V. Tamuzs, "Mode II delamination of a unidirectional carbon fiber/epoxy composite in four-point bend endnotched flexure tests," Mechanics of Composite Materials, vol. 41, no. 5, pp. 383-390, 2005.

[34] A. J. Vinciquerra and B. D. Davidson, "Effect of crack length measurement technique and data reduction procedures on the perceived toughness from four-point bend end-notched flexure tests," Journal of Reinforced Plastics and Composites, vol. 23, no. 10, pp. 1051-1062, 2004.

[35] R. H. Martin and B. D. Davidson, "Mode II fracture toughness evaluation using four point bend, end notched flexure test," Plastics, Rubber and Composites, vol. 28, no. 8, pp. 401-406, 1999.

[36] V. A. Franklin and T. Christopher, "Fracture energy estimation of DCB specimens made of glass/epoxy: an experimental study," Advances in Materials Science and Engineering, vol. 2013, Article ID 412601, 7 pages, 2013. 
[37] V. A. Franklin and T. Christopher, "Generation and validation of crack growth resistance curve from DCB specimens: an experimental study," Strength of Materials, vol. 45, no. 6, pp. 674-683, 2013.

[38] V. Alfred Franklin, T. Christopher, and B. Nageswara Rao, "Influence of root rotation on delamination fracture toughness of composites," International Journal of Aerospace Engineering, vol. 2014, Article ID 829698, 12 pages, 2014.

[39] R. H. Martin, T. Elms, and S. Bowron, "Characterization of mode II delamination using the 4ENF", in Proceedings of the 4th European Conference on Composites: Testing \& Standardisation, pp. 161-170, 1998.

[40] P. Hansen and R. H. Martin, "DCB, 4ENF and MMB delamination characterisation of S2/8552 and IM7/8552," in Proceedings of the 15th Annual Technical Conference on Composite Materials, 2000.

[41] A. Korjakin, R. Rikards, F.-G. Buchholz, H. Wang, A. K. Bledzki, and A. Kessler, "Comparative study of interlaminar fracture toughness of GFRP with different fiber surface treatments," Polymer Composites, vol. 19, no. 6, pp. 793-806, 1998.

[42] A. Szekrényes, Delamination of composite specimens [Ph.D. dissertation], Budapest University of Technology and Economics, Budapest, Hungary, 2005.

[43] F. Ozdil and L. A. Carlsson, "Beam analysis of angle-ply laminate mixed-mode bending specimens," Composites Science and Technology, vol. 59, no. 6, pp. 937-945, 1999.

[44] S. Hashemi, J. Kinloch, and J. G. Williams, "The effects of geometry, rate and temperature on mode I, mode II and mixed-mode I/II interlaminar fracture toughness of carbon-fibre/poly(etherether ketone) composites," Journal of Composite Materials, vol. 24, no. 9, pp. 918-956, 1990.

[45] S. Hashemi, A. J. Kinloch, and J. G. Williams, "Mechanics and mechanisms of delamination in a poly(ether sulphone)-Fibre composite," Composites Science and Technology, vol. 37, no. 4, pp. 429-462, 1990.

[46] H. Albertsen, J. Ivens, P. Peters, M. Wevers, and I. Verpoest, "Interlaminar fracture toughness of CFRP influenced by fibre surface treatment: part 1. Experimental results," Composites Science and Technology, vol. 54, no. 2, pp. 133-145, 1995.

[47] J. J. Polaha, B. D. Davidson, R. C. Hudson, and A. Pieracci, "Effects of mode ratio, ply orientation and precracking on the delamination toughness of a laminated composite," Journal of Reinforced Plastics and Composites, vol. 15, no. 2, pp. 141-173, 1996.

[48] C. Dahlen and G. S. Springer, "Delamination growth in composites under cyclic loads," Journal of Composite Materials, vol. 28, no. 8, pp. 732-781, 1994.

[49] B. D. Davidson and K. L. Koudela, "Influence of the mode mix of precracking on the delamination toughness of laminated composites," Journal of Reinforced Plastics and Composites, vol. 18, no. 15, pp. 1408-1414, 1999.

[50] J. W. Gillespie, L. A. Carlsson, R. B. J. Pipes, R. Rothschilds, B. Trethewey, and A. Smiley, "Delamination growth in composite materials,” NASA-CR 178066, 1986. 

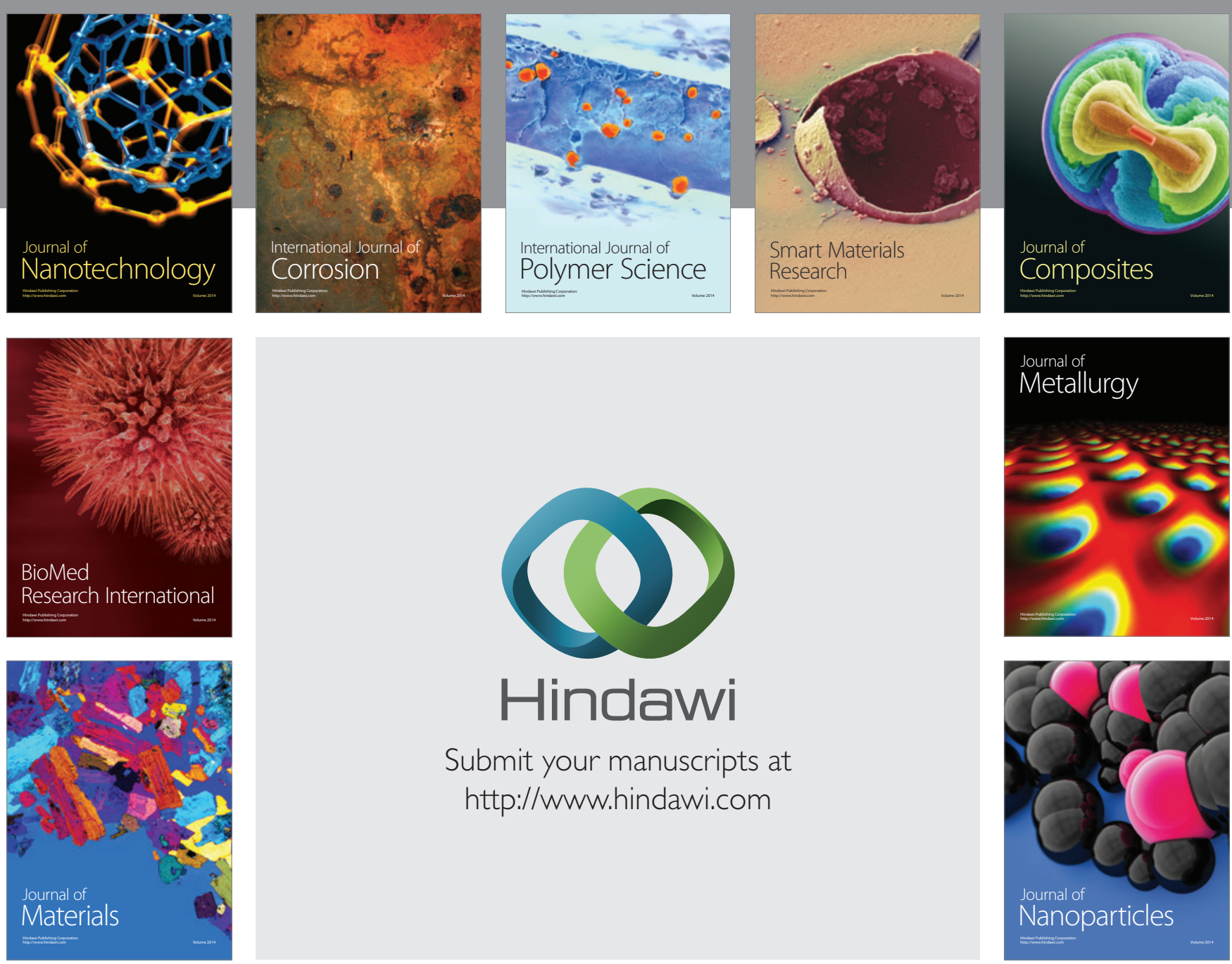

Submit your manuscripts at http://www.hindawi.com
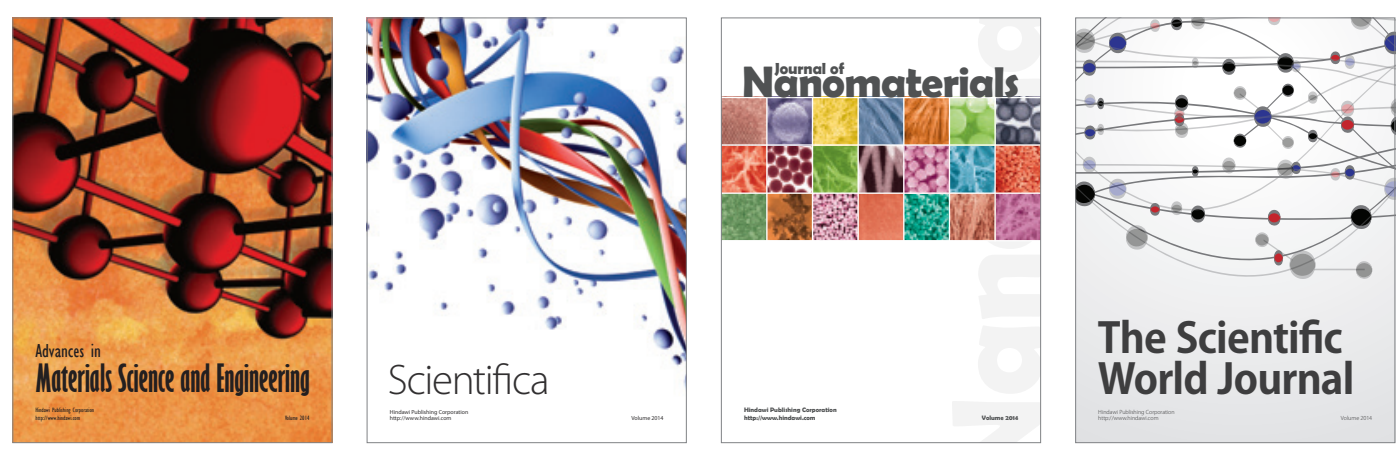

\section{The Scientific World Journal}
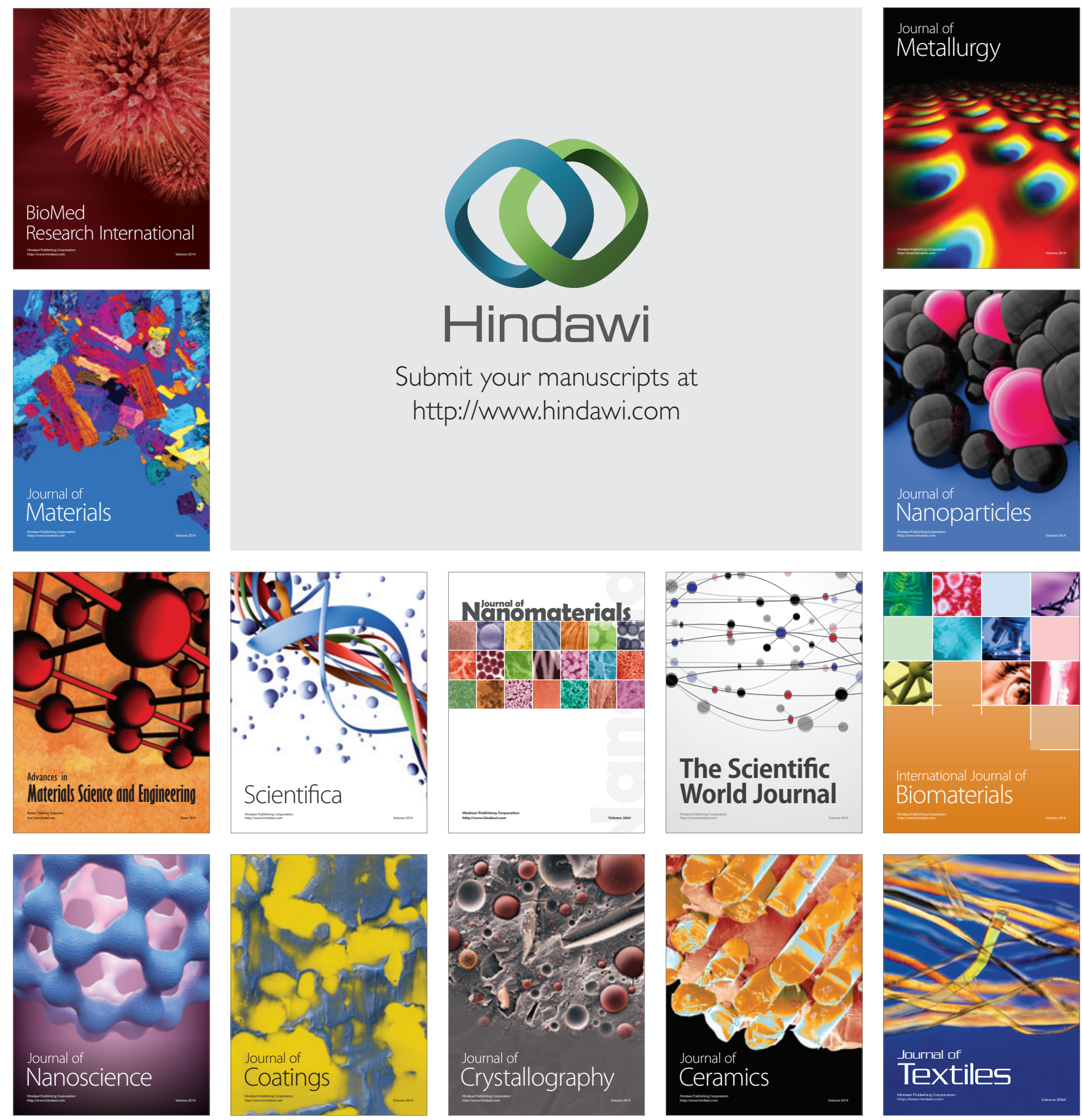